\title{
Author Correction: Analysis of mutations in pncA reveals non- overlapping patterns among various lineages of Mycobacterium tuberculosis
}

\author{
Ramani Baddam ${ }^{1,6}$, Narender Kumar ${ }^{2}$, Lothar H. Wieler ${ }^{1}$, Aditya Kumar Lankapalli, ${ }^{3,7}$, \\ Niyaz Ahmed ${ }^{3,4}$, Sharon J. Peacock (iD ${ }^{2,5}$ \& Torsten Semmler (i) ${ }^{1}$
}

Correction to: Scientific Reports https://doi.org/10.1038/s41598-018-22883-9, published online 15 March 2018

The Acknowledgements section in this Article is incomplete.

"We thank Dr. Astrid Lewin for her helpful discussion concerning the mechanism of PZA action. This publication presents independent research supported by the Health Innovation Challenge Fund (WT098600, HICF-T5-342), a parallel funding partnership between the Department of Health and Wellcome Trust. The views expressed in this publication are those of the author(s) and not necessarily those of the Department of Health or Wellcome Trust."

should read:

"We thank Dr. Astrid Lewin for her helpful discussion concerning the mechanism of PZA action. This publication presents independent research supported by the MRC-DBT funded partnership between National Institute for Research in Tuberculosis, Chennai and University of Cambridge (MR/N501864/1, NK). The views expressed in this publication are those of the author(s) and not necessarily those of the MRC or DBT."

(c) (i) Open Access This article is licensed under a Creative Commons Attribution 4.0 International License, which permits use, sharing, adaptation, distribution and reproduction in any medium or format, as long as you give appropriate credit to the original author(s) and the source, provide a link to the Creative Commons license, and indicate if changes were made. The images or other third party material in this article are included in the article's Creative Commons license, unless indicated otherwise in a credit line to the material. If material is not included in the article's Creative Commons license and your intended use is not permitted by statutory regulation or exceeds the permitted use, you will need to obtain permission directly from the copyright holder. To view a copy of this license, visit http://creativecommons.org/licenses/by/4.0/.

(C) The Author(s) 2018

${ }^{1}$ Robert Koch Institute, Berlin, 13353, Germany. ${ }^{2}$ Department of Clinical Medicine, University of Cambridge, Cambridge, CB2 00Q, United Kingdom. ${ }^{3}$ Department of Biotechnology and Bioinformatics, Pathogen Biology Laboratory, School of Life Sciences, University of Hyderabad, Hyderabad, 500084, India. ${ }^{4}$ Laboratory Sciences and Services Division, International Centre for Diarrhoeal Disease Research Bangladesh, Dhaka, 1212, Bangladesh. ${ }^{5}$ London School of Hygiene and Tropical Medicine, London, WC1E 7HT, United Kingdom. ${ }^{6}$ Present address: Laboratory Sciences and Services Division, International Centre for Diarrhoeal Disease Research Bangladesh, Dhaka, Bangladesh. ${ }^{7}$ Present address: Department of Archaeogenetics, Max Planck Institute for the Science of Human History, Jena, Germany. Correspondence and requests for materials should be addressed to T.S. (email: SemmlerT@ rki.de) 